Jurnal Riset Agama

Volume 1, Nomor 3 (Desember 2021): 292-306

DOI: 10.15575/jra.v1i3.15594

https://journal.uinsgd.ac.id/index.php/jra

\title{
Seni Mural Di Kecamatan Majalaya: \\ Tinjauan Filsafat Seni Leo Tolstoy
}

\author{
Tiara Rahma Kurnia \\ Jurusan Aqidah dan Filsafat Islam, Fakultas Ushuluddin \\ UIN Sunan Gunung Djati Bandung \\ tiara8804@gmail.com
}

\begin{abstract}
The purpose of this study was to analyze mural art in Majalaya sub-district in terms of the art philosophy of Leo Tolstoy. This study uses a qualitative approach with the type of field research. The results and discussion of this reseach include mural art in Majalaya District, Leo Tolstoy philosophy of art, and analysis of mural art in Majalaya District in terms of Leo Tolstoy art philosophy. The conclusion of this study is that mural art in Majalaya District in terms of principles and practice is relevant to Leo Tolstoy's philosophy of art. The research is recommended for further and in-depth research on mural art and other arts in order to support its existence, especially in Majalaya District.
\end{abstract}

Keywords: Art Philosophy; Leo Tolstoy; Mural Art.

\begin{abstract}
Abstrak
Tujuan penelitian ini adalah untuk menganalisis seni mural di Kecamatan Majalaya ditinjau melalui filsafat seni Leo Tolstoy. Penelitian ini menggunakan pendekatan kualitatif dengan jenis penelitian lapangan. Adapun hasil dan pembahasan penelitian meliputi seni mural di Kecamatan Majalaya, filsafat seni Leo Tolstoy, dan analisis seni mural di Kecamatan Majalaya ditinjau dari filsafat seni Leo Tolstoy. Kesimpulan penelitian ini adalah bahwa seni mural di Kecamatan Majalaya dari segi prinsip dan praktik relevan dengan filsafat seni Leo Tolstoy. Penelitian ini direkomendasikan agar adanya penelitian lebih lanjut dan mendalam mengenai seni mural maupun seni lainnya sehingga dapat mendukung eksistensinya terkhusus di Kecamatan Majalaya.
\end{abstract}

Kata kunci: Filsafat Seni; Leo Tolstoy; Seni Mural. 
Jurnal Riset Agama, Volume 1, Nomor 3 (Desember 2021): 292-306

Tiara Rahma Kurnia/Seni Mural Di Kecamatan Majalaya: Tinjauan Filsafat Seni Leo Tolstoy

\section{Pendahuluan}

Seni mural merupakan seni yang hadirnya selalu memiliki pembekalan makna dan tujuan. Zaman dahulu hingga sekarang mural dikenal sebagai media dalam menyampaikan ungkapan, kritik, yang dituangkan dalam bentuk gambar serta tulisan di atas permukaan dinding. Namun saat ini, mural tidak hanya sebagai penyampai kritik saja, tetapi mural mulai bergerak dalam fungsi lain yaitu dalam bidang bisnis misalnya untuk mempercantik suatu interior dan menjadikan suatu tempat agar memiliki daya tarik tersendiri sesuai dengan tema yang diminta oleh pemilik usaha (IMURAL, 2021). Oleh karena itu, mural terkadang menjadi suatu profesi bagi sebagian pelaku mural. Berbicara tentang kegiatan menggambar di atas permukaan dinding, ini merupakan kegiatan yang sudah pernah dilakukan dari zaman rasejarah tepatnya era Mesolitikum. Manusia-manusia zaman Mesolitikum ini berkegiatan menggambar dan menulis bertujuan untuk meninggalkan jejak serta pesan bahwa mereka pernah hidup di tempat tersebut, misalnya di suatu gua yang pernah dihuni oleh mereka.

Jika ditelusuri lebih lanjut keberadaan mural di Indonesia, dapat dilihat pada peristiwa perang melawan penjajah demi sebuah kemerdekaan. Kegiatan mural tersebut bermaksud untuk menyampaikan pesan pada masyarakat Indonesia untuk terus berjuang dan bersemangat melawan penjajah, yakni pada mural "Merdeka ataoe Mati" (Nababan, 2019).

Salah satu tokoh filsafat seni Leo Tolstoy memberi gagasan tentang seni bahwa seni itu bukan hanya perihal emosi secara estetik tapi lebih dalam daripada itu, ia berhubungan dengan luapan ekspresi yang dirasakan oleh seseorang atau siapapun lalu mencari cara agar ekspresi tersebut bisa sampai kepada orang lain, terlebih jika terkait kritikan publik, himbauan maupun ajakan. Maka sangat diperlukan suatu media untuk menjadi peluang yang tepat agar ekspresi tersebut bisa sampai lebih cepat kepada publik salah satunya melalui seni mural (Sunarto, Seni sebagai Ekspresi Emosi (Telaah Hakiki dan Nilai Seni dalam Ekspresivisme), 2017). Namun, akhir-akhir ini terjadi peristiwa hangat pada bulan Agustus 2021, tentang penghapusan mural yang berbau kritik yang terjadi di beberapa kota yaitu Bandung, Tangerang, dan Pasuruan Jawa Timur. Di Bandung terdapat lukisan mural yang diduga mirip Presiden Jokowi yang bagian wajahnya ditutup masker dan kemudian dihapus oleh kelompok pemerintah pada tanggal 23 Agustus 2021 karena dianggap penghinaan lambang negara. Kemudian di Ciledug kota Tangerang mural "wabah sesungguhnya adalah kelaparan" dan "Tuhan aku lapar!!" yang dihapus pada tanggal 17 Agustus 2021 karena dianggap bersifat provokatif dan melanggar pengelolaan kebersihan. Kemudian di Pasuruan Jawa Timur mural yang bertuliskan "dipaksa sehat di negara yang sakit" dihapus pada 
Jurnal Riset Agama, Volume 1, Nomor 3 (Desember 2021): 292-306

Tiara Rahma Kurnia/Seni Mural Di Kecamatan Majalaya: Tinjauan Filsafat Seni Leo Tolstoy

tanggal 10 Agustus 2021 lagi-lagi dianggap bersifat provokatif. Dan terakhir di Batu Ceper kota Tangerang juga ada mural yang mirip presiden Jokowi serta bertuliskan "404:Not Found" dihapus tanggal 12 Agustus 2021 tidak lain lagi karena dianggap sebagai penghinaan lambang negara (TvOneNews, 2021). Peristiwa ini membuat masyarakat banyak yang berkomentar, namun sebagian besar dari mereka kecewa akan tindakan pemerintah ini, terlihat dari salah satu konten youtube yang mencoba membahas terkait permasalahan ini sehingga membuat para seniman ikut membuka mulut di antaranya mas Eko Nugroho, yaitu selaku seniman senior Jogja yang sering menyuarakan persoalan sosial politik sejak era reformasi, yang sengaja diundang untuk berpendapat tentang peristiwa mural ini, bersama David selaku pembawa acara konten youtube tersebut bahwasanya mas Eko Nugroho mengatakan "kalau menghapus karya seni tersebut di negara yang makmur itu tidak akan menjadi masalah, karena semua orang sudah kenyang" beliau juga berkata "justru seni mural ini lebih beradab daripada kita harus ricuh di jalanan, lalu apa titik aturan sebuah kritik dianggap beradab atau tidaknya," selain mas Eko Nugroho ada pula tokoh seni perempuan yakni Bunga Fatia selaku seniman grafity pendiri Ladies on Wall yang juga ikut diwawancara dalam acara konten youtube tersebut, ia mengatakan "mungkin menurut mereka (pemerintah) karya yang beradab itu kalau karyanya memuji-muji mereka." Dalam video tersebut juga terjadi dialog langsung dengan pelaku mural "Tuhan aku lapar!!" beliau menceritakan bahwa sudah 12 tahun berkarya namun baru kali ini karyanya ditolak oleh pemerintah sehingga harus dilakukan penghapusan, dia mengaku merasa aneh ketika diminta untuk membuat video permintaan maaf karena mural yang ia buat dianggap provokatif oleh pemerintah dan ia juga mengaku diberi bansos oleh pemerintah untuk memastikan bahwa tim mural ini dalam keadaan tidak kelaparan pada saat membuat mural, padahal dia masih bingung bahwa mural yang dia buat itu dia rasa tidak bersifat kriminal dia hanya menyampaikan kritik perihal situasi yang dialami selama pandemi, namun pelaku seni mural yang bernama Ohaiyoh ini mengaku bahwa peristiwa ini tidak membuatnya berniat berhenti berkarya justru dia akan terus bermural (Narasi, 2021). Di dalam berita media online yang berbeda ditayangkan komentar seorang budayawan Sujiwo Tejo terkait tindakan pemerintah ini, beliau mengatakan bahwa mural itu jangan dihapus, justru menghapus sesuatu yang fisik itu akan menempel di dalam kenangan, beliau menganggap mural dapat menjadi suatu penghilang kepenatan untuk masyarakat karena setiap orang itu butuh refleksi, perihal bermural sebenarnya kita tidak perlu izin kepada siapapun kita hanya perlu meminta izin pada yang punya tempat. (tvOneNews, 2021). Karya mural yang berbentuk kritik saat ini seakan sedang menjadi polemik dan menjadi sesuatu yang dibatasi keberadaannya padahal presiden Jokowi telah mengeluarkan statement 
Jurnal Riset Agama, Volume 1, Nomor 3 (Desember 2021): 292-306

Tiara Rahma Kurnia/Seni Mural Di Kecamatan Majalaya: Tinjauan Filsafat Seni Leo Tolstoy

bahwasanya mural tidak perlu dihapus karena itu merupakan karya seni dan semoga bisa membuat orang terhibur dan memunculkan rezeki yang banyak bagi para pelaku seni mural (TvOneNews, 2021).

Pada konteks seni mural yang ada di Kecamatan Majalaya Kabupaten Bandung, terdapat pelaku seni mural yang juga penduduk asli Kecamatan Majalaya, pelaku seni mural ini cukup aktif bergerak di Kawasan Majalaya seperti di antaranya mereka pernah melukis di dinding kawasan Citarum Majalaya dengan sejumlah pesan yang akan disampaikan melalui lukisan mural tersebut, yakni berhubungan dengan keadaan sosial di mana Kawasan Citarum tersebut kurang begitu mendapat perhatian masyarakat perihal kebersihannya, sampah berserakan, sehingga banjir masih sering terjadi di Kawasan tersebut, dan penghijauan yang terlupakan membuat Kawasan Citarum terlihat gersang, maka dalam lukisan mural yang dilukis di Kawasan tersebut mencoba memberikan kesadaran kepada masyarakat untuk lebih merawat lingkungan dengan melakukan reboisasi dan semacamnya. Selain bernuansa alam, pelaku seni ini pun sering melakukan pelukisan di sejumlah Kafe yang ada di Kecamatan Majalaya yang bergantung pada permintaan pemilik Kafe. Salah satu pelaku seni di Kecamatan Majalaya ini pun pernah melukis mural di luar wilayah yakni di Bali. Dengan ini, peneliti merasa perlu melakukan penelitian terkait mural dari sisi filosofis yang mendasarkan pada tinjauan filsafat seni khususnya melalui tokoh filsafat seni Leo Tolstoy.

Melihat kepada penelitian-penelitian sebelumnya, ditemukan beberapa penelitian yang hampir sama, dalam arti menggunakan pisau analisis yang sama atau tema pembahasan yang sama. Dari beberapa di antaranya itu, penelitian yang dilakukan oleh Muhammad Fahriansyah Agil yang merupakan mahasiswa fakultas filsafat UGM Tahun 2019 yang diterbitkan di Perpustakaan Online UGM yang berjudul "Stand Up Comedy Tinjauan Filsafat Seni Leo Tolstoy," lalu juga "Tinjauan Filsafat Seni Gilles Deleuze Terhadap Kredo Jiwa Ketok S. Sudjojono" yang diteliti oleh Sudaryanto Aang Apriyanto, merupakan akademisi UGM Tahun 2015 yang juga diterbitkan di Perpustakaan Online UGM, "Tinjauan Filsafat Seni terhadap Tata rias dan busana pengantin Paes Ageng Kanigaran Gaya Yogyakarta" yang diteliti oleh Sri Widayanti merupakan akademisi UGM Tahun 2011 yang terbit di Jurnal UGM, "Kaligrafi Islam dalam perspektif Filsafat Seni" yang diteliti oleh Syahrul Kirom dan Alif Lukmanul Hakim yang merupakan mahasiswa jurusan Aqidah dan Filsafat Islam Fakultas Ushuluddin dan Pemikiran Islam UIN Sunan Kalijaga Yogyakarta, penelitian “Tinjauan Filsafat Seni Arthur Danto terhadap karya musik Orkes Moral pengantar minum racun (OM PMR)" yang diteliti oleh Sudaryanto Azhar Zein Amrulloh dan Sindung Tiahyadi merupakan akademisi UGM tahun 2018, dan lain-lain. Masih banyak penelitian-penelitian yang senada dengan penelitian yang akan dilakukan oleh peneliti, namun dari penelitian-penelitian sebelumnya 
Jurnal Riset Agama, Volume 1, Nomor 3 (Desember 2021): 292-306

Tiara Rahma Kurnia/Seni Mural Di Kecamatan Majalaya: Tinjauan Filsafat Seni Leo Tolstoy

lebih membahas pada objek seni yang lain, dari keberagaman seni inilah peneliti ingin mencoba mengangkat seni mural di Kcamatan Majalaya sebagai objek penelitian dalam tinjauan filsafat seni Leo Tolstoy.

Fokus penelitian ini adalah mengkaji seni mural di Kcamatan Majalaya dengan tinjauan filsafat seni Leo Tolstoy. Untuk mengkaji penelitian ini peneliti memakai teori dari Leo Tolstoy untuk mencari nilainilai filsafat seni yang terkandung dalam seni Mural tersebut.

Seni yaitu setiap hal yang dihasilkan oleh insan di muka bumi ini serta mengandung unsur indah yang dapat menggugah rasa antara dirinya juga orang lain (Ahmad, 2020). Dalam filsafat seni lebih menekankan pada sisi ekspresi yang di mana teori ekspresi itu bertentangan dengan teori imitasi (Binus, 2013). Menurut Leo Tolstoy bahwa karya seni adalah sebuah simbol yang dapat dijadikan media komunikasi serta dapat membangkitkan emosi audience. Emosi yang dimaksud oleh Leo Tolstoy bukan hanya berupa emosi estetik namun juga emosi moral. Dengan demikian diperlukan sebuah interpretasi moral supaya semua orang dapat menangkap pesan moral yang terdapat di dalam sebuah karya seni (Rondhi, 2017). Leo Tolstoy mengatakan "he stronger the infection the better is the art" yang berarti ketika karya seni semakin mampu membangkitkan emosi pemirsa, maka karya seni tersebut semakin berhasil. Di samping emosi estetik, secara moral Leo mengatakan bahwa seni yang sejati akan mampu mengkomunikasikan dan membangkitkan sesuatu yang nilainya mulia, dan bukan sejenis perasaan yang rendah misalnya seksualitas (Sunarto, Seni sebagai Ekspresi Emosi (Telaah Hakiki dan Nilai Seni dalam Ekspresivisme), 2017). Leo Tolstoy menganggap bahwa ekspresi yang diberikan oleh seorang seniman itu beragam, bisa bersifat kuat bisa juga lemah, bisa penting bisa juga tidak penting, bisa baik ataupun buruk. Sifat tersebut bisa diterima melalui indera yang menjadikannya pengalaman seni bagi manusia itu sendiri.

Bagi Leo Tolstoy ada tiga syarat utama seni, yakni: 1) Besar dan kecilnya kepribadian seniman berpengaruh besar terhadap nilai ekspresi, Tolstoy meyakini bahwa semakin menonjol individualitas seniman maka semakin maksimal dalam mempengaruhi penerimanya, karena individu seniman mencerminkan bobot sikap jiwa seniman; 2) Besar kecilnya suatu kejelasan dan kemurnian perasaan yang diungkapkan seniman berpengaruh besar terhadap nilai ekspresi. Karena dengan begitu merupakan cara mengembalikan perasaan yang bisa jadi telah lama tidak dirasakan; dan 3) Tingkat kejujuran seniman pun menjadi pengaruh besar pula terhadap nilai seni (Thabroni, 2018).

Melihat kasus-kasus atau tindakan pemerintah terhadap seni mural yang baru-baru ini terjadi di Indonesia, serta melihat keberadaan seni mural yang masih bergerak aktif di kawasan Majalaya, peneliti berasumsi perlu untuk meneliti seni mural ini yang mencoba untuk mengkhususkan 
Jurnal Riset Agama, Volume 1, Nomor 3 (Desember 2021): 292-306

Tiara Rahma Kurnia/Seni Mural Di Kecamatan Majalaya: Tinjauan Filsafat Seni Leo Tolstoy

penelitian satu wilayah Kecamatan Majalaya. Satu pertanyaan utama yang akan diangkat, yaitu bagaimana tinjauan filsafat seni Leo Tolstoy terhadap seni Mural di Kecamatan Majalaya? Besar harapan penelitian ini dapat bermanfaat bagi pembaca, baik sebagai wawasan pengetahuan, tambahan referensi, dan menjadi motivasi untuk tetap melestarikan serta mengembangkan kesenian di daerah masing-masing dengan adanya penelitian ini.

\section{Metode Penelitian}

Pada penelitian ini peneliti menggunakan pendekatan kualitatif. Metode penelitian ini bertujuan untuk memahami objek yang diteliti tersebut secara mendalam (Gunawan, 2015). Jenis penelitian yang diterapkan merupakan penelitian lapangan dimana peneliti akan terjun langsung memahami kegiatan yang akan diteliti oleh sang aktor dalam hal ini sang pelaku mural (Azwar, 1999, hal. 21). Adapun "memahami" atau dalam bahasanya Max Weber disebut dengan "verstehen" merupakan suatu metode yang bisa dipahami sebagai tindakan aktor yang mencakup kehidupan dan menjadi dasar bagi tindakan aktor tersebut (Pandu Pramudita, 2018, p. 97). Sedangkan metode yang akan ditempuh selama di lapangan yaitu metode studi kasus yang mendasarkan pada sumber data yang diterapkan yaitu ada dua macam sumber data primer dan sekunder. Sumber data primer peneliti dapatkan langsung dari pelaku mural di Kawasan Majalaya yaitu 3 pelaku seni mural yang dilakukan wawancara. Sedangkan data sekunder peneliti dapatkan dari sumber-sumber sebagai penunjang di antaranya, buku, arsip, jurnal, informasi dari keluarga, desa setempat, dan lain-lain.

Adapun proses tahapan yang akan dilalui dalam penelitian ini berangkat dari menentukan pendekatan, dimana peneliti memutuskan menggunakan pendekatan kualitatif dengan menerapkan jenis penelitian lapangan. Setelah itu, peneliti menentukan informan atau narasumber untuk dijadikan sebagai sumber data primer yang nantinya akan didapatkan informasi melalui sebuah wawancara, lalu mencari sumbersumber sekunder sebagai bahan penunjang, kemudian melakukan pengumpulan data, analisis data dan yang terakhir menarik kesimpulan. 
Jurnal Riset Agama, Volume 1, Nomor 3 (Desember 2021): 292-306

Tiara Rahma Kurnia/Seni Mural Di Kecamatan Majalaya: Tinjauan Filsafat Seni Leo Tolstoy

\section{Hasil dan Pembahasan}

Seni merupakan suatu kebutuhan manusia untuk mengungkapkan ekspresi dan merasakan kepuasan keindahan. Ki Hajar Dewantara mengatakan tentang seni bahwa seni merupakan seluruh tingkah laku manusia yang berasal dari rasa dirinya yang sifatnya indah, kemudian mampu menyentuh jiwa dan hati manusia, maka, seni dikatakan mengandung kebaikan serta kebenaran. Seni termasuk ke dalam ranah atau wilayah rohaniyah, dimana rasa rohaniyah ini terdiri dari enam unsur, yaitu rasa etika, agama, sosial, intelek, estetik dan yang terakhir rasa dari diri sendiri (Mawardi, 1970). Namun begitu, memang tidak dipungkiri seni pun berhubungan dengan jasmaniyah yaitu berupa keterampilan, namun memang secara lebih dalam sangat erat kaitannya dengan rasa. Oleh karena itu seni berbicara tentang mengungkapkan rasa dalam bentuk simbolis atau melalui sebuah karya (Islam \& Ukir, n.d.).

Menurut Dharsono bahwa antara seni dengan masyarakat itu menjadi dua hal yang masing-masing mempunyai kepentingan pribadi dan masalah pribadi, namun ia pun menegaskan antara keduanya memiliki suatu hubungan yang tak dapat terpisahkan (Iswandi, 2016) sehingga seni sering dijadikan sebuah media bagi para seniman untuk menyampaikan gagasannya (Sobur, 2007). Sedangkan selain sebagai media, seni juga memegang peranan sebagai bentuk ekspresi, karena setiap seniman dalam karyanya sebagian besar berasal dari suasana emosi dirinya yang kemudian diekspresikan, oleh karenanya keberhasilan seni bisa dinilai dari seberapa dalam seniman menyuntikan perasaannya kepada audience (Ratu, 2016).

Seni mural merupakan salah satu karya seni yang memiliki kontribusi bagi kehidupan sosial selain dapat dinikmati keelokannya. Kata mural berasal dari kata murus yang artinya adalah dinding, karenanya seni mural merupakan salah satu seni lukis yang biasanya memakai media tembok atau media lainnya seperti papan besi, langit-langit ataupun kain. Sedangkan menurut Susanto, mural adalah lukisan besar yang dibuat guna memperindah ruang arsitekstur. Mural berbeda dengan lukisan biasa, letak perbedaannya yaitu syarat yang harus ditempuh oleh seni mural ini, misalnya perizinan tempat pelukisan serta merupakan desain dengan ukuran yang besar (Nababan, 2019).

Keberadaan mural sudah banyak diakui oleh khalayak khususnya di Indonesia, bahkan saat ini mural menjadi perhatian masyarakat juga pemerintah, mulai dari mural yang syarat akan kebutuhan kapitalisme (beriklan) sampai mural yang menyiratkan pesan-pesan atau yang berhubungan dengan kritik sosial. Eksistensi mural di Indonesia hingga kini tentu tidak terlepas dari konsistensi dari sang pelaku mural yang istiqomah melawan arus dan rintangan untuk tetap bermural (Nababan, 2019). Mural mewujudkan dirinya sebagai visual dan juga verbal. Bentuk 
Jurnal Riset Agama, Volume 1, Nomor 3 (Desember 2021): 292-306

Tiara Rahma Kurnia/Seni Mural Di Kecamatan Majalaya: Tinjauan Filsafat Seni Leo Tolstoy

gambar dalam mural yang berhubungan dengan bentuk dan warna diartikan sebagai visual dan teks yang disandingkannya diartikan sebagai verbal (Candra, 2013).

Melirik pada sejarah, seni rupa mencatat karya seni mural yang paling terkenal adalah karya Pablo Picasso Guernica dan Guernica y Luno yang hadir ketika perang sipil di Spanyol pada tahun 1937. Sedangkan karya mural yang terkenal di Indonesia jatuh pada momentum perang demi kemerdekaan lebih tepatnya mural yang bertuliskan "Boeng Ajoe Boeng" dan "Merdeka Ataoe Mati" (Nababan, 2019). Mural mulai maju dan berkembang ke arah modern pada tahun 1920 yaitu di Meksiko bersama beberapa pelopor di antaranya Diego Rivara, David Alfaro, juga Jose Clemente Orozco.

Dilandasi oleh keadaan pemerintahan yang rumit membuat mural naik ke permukaan dan menjelma sebagai lahan baru untuk menampung aspirasi-aspirasi masyarakat yang berada di fase galau karena setiap harinya disuguhkan aktivitas-aktivitas pejabat pemerintah yang kacau dengan wakil-wakil rakyat yang tidak bermoral, lalu korupsi, dan lain-lain (Candra, 2013) maka mural hadir sebagai respon reaktif dari masyarakat terhadap kondisi lingkungannya (Pandanwangi et al., 2021). Salah satu perbincangan juga di wilayah perkotaan karena memang kota menjadi salah satu sasaran perbaikan tatanan kehidupan, bersama dengan berkembangnya perindustrian di wilayah tersebut disertai dampak yang kemudian dirasakan, selain itu kerusakan ekologi berupa kepulan asap kendaraan dan kegersangan akibat minimnya populasi pepohonan (Obed Bima Wicandra, 2005).

Karena mural disebut-sebut sebagai media alternatif seni visual yang berperan sebagai wadah gagasan masyarakat yang bernuansa kritik, informasi peristiwa juga termasuk sarana pengikat batin antara masyarakat dengan seniman (Candra, 2013), maka seniman berupaya mem-publish karyanya agar karyanya bisa cepat sampai pada semua pihak karena pada dasarnya seni ada untuk publik (Art for Public) seperti yang disampaikan Plato bahwa seni dan masyarakat itu keterhubungan yang tak dapat dipisahkan tak ubahnya manusia dengan lingkungannya (Nababan, 2019).

Seni mural termasuk suatu seni yang tidak begitu terpengaruh terhadap kecanggihan teknologi saat ini, ketika jenis pembuatan karya seni lain mulai menggunakan sentuhan teknologi atau bahkan mungkin secara keseluruhan mengandalkan teknologi, namun mural masih menggunakan cara yang konvensional dengan tetap menggambar secara manual dalam proses pembuatannya. Contohnya Young Surakarta, beliau adalah pelaku mural yang masih istikamah bermural dengan metode konvensional, selain itu, contoh lainnya terjadi di Surabaya mengenai penyampaian kritik terhadap pemerintah melalui seni mural seputar amburadulnya penanganan Covid-19 yang berisikan suatu pesan perang melawan Covid- 
Jurnal Riset Agama, Volume 1, Nomor 3 (Desember 2021): 292-306

Tiara Rahma Kurnia/Seni Mural Di Kecamatan Majalaya: Tinjauan Filsafat Seni Leo Tolstoy

19. Dengan demikian, pengetahuan tentang mural melalui nilai instrinsik dan ekstrinsik yakni nilai estetika dan nilai moral yang telah peneliti paparkan sebelumnya menjadi suatu dasar untuk memaparkan bagaimana pelaku mural beserta karyanya masih tetap bereksistensi di zaman canggih apalagi di era 4.0 ini (ikilhojatim.com, 2020).

Berbicara mengenai seni mural, di Kecamatan Majalaya Kabupaten Bandung, terdapat sejumlah pelaku seni mural yang merupakan penduduk asli Kecamatan Majalaya. Majalaya merupakan suatu wilayah yang secara geografis terletak di sebelah Tenggara Kota Bandung sekitar $25 \mathrm{~km}$ atau setara dengan $35 \mathrm{~km}$ dari wilayah ibukota Kabupaten Bandung, Soreang. Majalaya sebagai suku Sunda merupakan salah satu wilayah yang padat penduduk dengan populasi yang dikatakan ramai. Sekitar tahun 1960an perekonomian di Kcamatan Majalaya sedang dalam fase yang maju, namun pada tahun 1990-1998 politik dan ekonomi menurun dan cenderung terpuruk, banyak pengusaha-pengusaha yang gulung tikar. Penjelasan lainnya bahwa Majalaya itu berposisi sebelah tenggara cekungan Bandung, dengan keadaan kontur tanah yang relatif datar kecuali di desa-desa tertentu yang sedikit tinggi atau menanjak, maka dari itu Majalaya terkenal dengan fenomena banjir yang sering terjadi.

Melihat dari salah satu karakter wilayah kecamatan Majalaya yang sering terjadi banjir serta terdapat lumayan banyak pelaku seni di wilayah tersebut membuat seni mural bisa menjadi salah satu media untuk berkontribusi bagi keadaan sosial di sekitar kawasan Majalaya (Wikipedia, 2021). Salah satu pelaku seni mural di Kecamatan Majalaya bernama Robi Maulana atau terkenal dengan nama panggilannya Obay Art mengakui, bahwa mereka masih cukup aktif bergerak di kawasan Majalaya seperti di antaranya mereka pernah melukis di dinding kawasan Citarum Majalaya dengan sejumlah pesan yang mencoba untuk disampaikan melalui lukisan mural tersebut, yakni berhubungan dengan keadaan sosial di mana kawasan Citarum tersebut kurang perhatian masyarakat perihal kebersihannya, sampah berserakan, sehingga banjir masih sering terjadi di kawasan tersebut juga penghijauan yang terlupakan membuat kawasan Citarum tersebut terlihat gersang, maka dalam lukisan mural yang dilukis di kawasan tersebut mencoba memberikan kesadaran kepada masyarakat untuk lebih menghargai lingkungan seperti melakukan reboisasi dan semacamnya. Selain bernuansa alam, pelaku seni ini pun sering melakukan pelukisan di sejumlah Kafe yang ada di Kecamatan Majalaya yang bergantung pada permintaan pemilik Kafe. Obay juga pernah melukis mural di luar wilayah yakni di Bali.

Menurut pendapat Obay:

"Peran mural menurut saya sebuah ungkapan ekspresi, kebutuhan hasrat berkesenian untuk mengungkapkan gambar ke media yang lebih besar agar bisa 
Jurnal Riset Agama, Volume 1, Nomor 3 (Desember 2021): 292-306

Tiara Rahma Kurnia/Seni Mural Di Kecamatan Majalaya: Tinjauan Filsafat Seni Leo Tolstoy

dinikmati banyak orang, melalui mural banyak yang saya dapat selain materi yang sudah didapat selama ada job mural, juga relasi orang-orang baik yang senantiasa menghargai seni, banyak kenalan di dunia seni dan secara tidak langsung mengenal banyak lagi arti seni."

Memaknai ungkapan ini artinya mural memiliki nilai penting bagi mereka di antaranya nilai estetis dan ekonomis. Selain mural juga pelaku seni mural ini mengaku pernah membuat seni phyrografi dalam acara nonton bareng film "sexy killer" dengan menggunakan alat solder, sesuai dengan tayangan filmnya proses pelukisan ini bertujuan sebagai bentuk tanggapan terhadap film "sexy killer" yang dilakukan di Kafe daerah Cikaro, Majalaya. lahan."

"Sebenarnya bisa aja pakai mural, tapi saat itu kurang support perihal

Selain itu juga masih banyak kegiatan-kegiatan muralnya. Menyinggung masalah kasus penghapusan mural di sejumlah kota, membuat pelaku mural di Majalaya ikut risih dengan kejadian itu, mereka mencoba menanggapi:

"Menurut saya amah teu etis kalo mesti dihapus mah kan seni mural emang dari dulu oge jadi salah sahiji cara komunikasi public anu paling ampuh, komo ninggal sistem pemerintahan di Indonesia menganut demokrasi masa mau dibungkam, harusnya ya intropeksi kan di samping membatasi kreativitas seniman mural juga menutup kritikan masukan dari masyarakat juga," ujar salah satu pelaku seni mural di Kecamatan Majalaya.

Menurut Obay, kalau bukan melalui mural dengan cara apalagi kritik kita dapat disampaikan agar didengar, harusnya masyarakat buka mata lebar-lebar masyarakat tidak akan mengkritik lewat mural jika tatanan pemerintahan sudah benar dan sehat, mungkin seniman akan lebih menciptakan mural terkait edukasi, tapi apa daya seniman berbicara apa adanya melalui mural.

Selain Obay, pelaku seni mural Majalaya lainnya, Luki Pratama dan Didin. Luki menganggap mural sebagai hal yang banyak berkontribusi dalam hidupnya, ia merasa ada kehidupan baru setiap kali bermural, karena sebelum bermural ia mengaku orang yang pendiem dan pemalu, tapi melalui mural ia bisa mengekspresikan pikirannya melalui mural. Dan bisa menjadi orang yang percaya diri dan berdamai dengan diri sendiri, mural cukup merubah dirinya dari segi psikologi. Sedangkan, menurut Didin mural itu sebagai daya Tarik bagi lingkungan dan melakukan ajakan-ajakan positif. Dengan mural yang dibuat olehnya membuat orang- 
Jurnal Riset Agama, Volume 1, Nomor 3 (Desember 2021): 292-306

Tiara Rahma Kurnia/Seni Mural Di Kecamatan Majalaya: Tinjauan Filsafat Seni Leo Tolstoy

orang menjadi tertarik untuk mengunjungi bahkan berfoto selfie dan mural yang berbentuk ajakan positif pernah ia lakukan melalui gambar gedung sate yang bertujuan agar masyarakat sekitar bangga atas ikon-ikon yang dimiliki oleh Kota Bandung, jadi, mural tidak hanya memiliki nilai estetika namun memiliki nilai moral.

Senada dengan fungsi seni mural yang telah disinggung, yakni sebagai nilai estetika yang dapat dinikmati khalayak juga sebagai ekspresi sang seniman yang bertujuan sebagai wadah aspirasi masyarakat dalam memperbaiki kehidupan sosial, politik, yang dituangkan melalui sebuah karya yaitu seni mural agar lebih mudah tembus ke publik. Maka, seorang sastrawan, novelis termuka juga disebut-sebut sebagai salah satu filsuf seni asal Rusia Lev Nikolayev Tolstoy, atau dengan nama harum Leo Tolstoy memiliki pandangannya tentang seni yang selaras dengan peran seni mural di Indonesia khususnya di Kecamatan Majalaya.

Leo Tolstoy lahir di tanah Yasnaya Polyana pada tahun 1828. Leo Tolstoy telah memiliki seorang istri yang bernama Sofia Andreyevna yang dinikahinya pada tahun 1862. Beliau sempat berkuliah di Universitas Kazan dan ia memilih untuk tidak meneruskannya (Chesterton, 1994) karena merasa tidak puas dengan metode pengajarannya (Muhammad, 2003). Lalu Tolstoy bergabung dengan resimen altileri atau ketentaraan pada tahun 1851 dan kembali lagi ia tinggalkan pada tahun 1856 setelah itu ia mulai bergabung dengan para sastrawan di St Petersburg (Tolstoy, n.d.).

Tolstoy memiliki banyak hasil karyanya baik itu buku ataupun novel, salah satu bukunya yang berjudul "what is art" Tolstoy memberikan sejumlah pandangannya tentang seni, bahwa baginya seni itu bukan hanya perihal keindahan namun juga sebagai bentuk ekspresi seniman yang disampaikan kepada publik dengan tujuan untuk membentuk manusia menjadi lebih sempurna baik secara jasmani, spiritual, psikologi dan sosial. Pada tahun 1870an Leo mengalami krisis spiritual hingga tahun 1879-1882 dalam hidup dan karyanya ia menjadi sosok yang rasionalis dan moralis(Tolstoy, n.d.) hingga pandangan Leo tentang seni lebih menonjolkan sisi moralnya bahwa pada dasarnya seniman itu mengungkapkan ekspresinya sesuai dengan apa yang dialami seniman tersebut, bukan untuk kepentingan pribadi melainkan untuk kepentingan orang banyak karena tujuan utama seni untuk ikut menyempurnakan hidup semua orang (Sumardjo, 2000). Leo tidak setuju dengan pandangan kaum-kaum pelajar jika seni merupakan suatu tingkah laku yang menciptakan sesuatu yang indah karena setiap orang itu mempunyai selera yang beragam, dianalogikan jika ada sebuah makanan yang dicicipi oleh dua orang, bisa saja satu orang mengatakan makanan tersebut amatlah enak, namun bisa saja satunya mengatakan makanan itu sangat menjijikan hal itu menunjukan bahwa yang dinamakan indah tidak selalu menjadi apa yang dibutuhkan kembali lagi makanan yang enak itu makanan yang 
Jurnal Riset Agama, Volume 1, Nomor 3 (Desember 2021): 292-306

Tiara Rahma Kurnia/Seni Mural Di Kecamatan Majalaya: Tinjauan Filsafat Seni Leo Tolstoy

bermanfaat bagi tubuh manusia dan itu boleh jadi makanan yang kita nilai tidak enak maka dari itu, perlu menyingkirkan point keindahan untuk mengatahui hakikat dari seni (Sumardjo, 2000).

Sejak Tolstoy berubah menjadi sosok moralis yang menjunjung tinggi kesederhanaan dan kebenaran itu dilandasi oleh keadaan sosial yang terjadi di Rusia kala itu, dimana adanya ketidakadilan antara rakyat dengan kelompok ningrat (Leo Tolstoy, 2007). Karya-karyanya yang bernuansa religius mengandung perenungan moral dan filsafat (Leo Tolstoy, 2009). Contohnya buah pemikirannya dalam novel "Tuan dan Hamba" yaitu tentang keberadaan Tuhan yang menemani dalam keseharian manusia, beliau mempercayai adanya Tuhan dan keyakinan dalam agama beliau mengatakan:

"Kadang orang itu menganggap suatu kejujuran itu salah ketika ada sisi-sisi lain yang menguasai orang tersebut, contohnya aturan" (Leo Tolstoy, 1983).

Selain itu juga dalam novel "kalender kearifan" banyak kalimat-kalimat Tolstoy yang menarik:

"Pertanyaan paling penting jaman kita adalah apakah kita melakukan hal yang benar selama periode waktu yang singkat ini yang disebut kehidupan, dan apakah perbuatan kita sesuai dengan kehendak Tuhan yang mengirim kita pada kehidupan ini. Apakah kita melakukan perbuatan yang benar?" (Leo Tolstoy, 2003).

"Semua sejarah umat manusia sejak kita mengenalnya adalah gerakan kemanusiaan menuju penyatuan yang kian hari kian erat" (Leo Tolstoy, 2003).

"Orang yang menolak kebebasan laksana orang buta yang menolak adanya warna, mereka tidak tau sifat dasar kebebasan" (Leo Tolstoy, 2003).

"Mempercayai adanya satu dzat yaitu Tuhan ketika semua orang tidak mempercayai kejujuran kita" (Leo Tolstoy, 1983).

"Jika manusia tidak memiliki kapasitas lain (seni) orang mungkin akan lebih biadab dan diatas segalanya lebih terpecah dan bermusuhan" (Tolstoy, n.d.).

Dari berbagai pemikiran Leo Tolstoy tentang seni yang bertolak belakang pada wilayah moral, religius, dan kemanusiaan yang menjunjung tinggi kebenaran dan kejujuran, peneliti rasa relevan untuk menjawab permasalahan yang telah terjadi di Indonesia tentang penghapusan mural pada bulan Agustus lalu juga dengan eksistensi mural khususnya di Kecamatan Majalaya. Dalam kalimat Tolstoy "jika manusia tidak memiliki 
Jurnal Riset Agama, Volume 1, Nomor 3 (Desember 2021): 292-306

Tiara Rahma Kurnia/Seni Mural Di Kecamatan Majalaya: Tinjauan Filsafat Seni Leo Tolstoy

kapasitas lain (seni) orang mungkin akan lebih biadab dan di atas segalanya lebih terpecah dan bermusuhan" (Tolstoy, n.d.) mengandung makna bahwa seni itu dapat menjadikan diri seseorang menjadi orang yang ekspresif dalam arti menyalurkan segala permasalahan melalui karya bukan melalui tindakantindakan anarkis contohnya pada mural yang dilakukan penghapusan sebenarnya para pelaku seni itu sudah melakukan sesuatu yang lebih mulia dalam menghadapi ketidakadilan di pemerintahan. "Kadang orang itu menganggap suatu kejujuran adalah salah ketika ada sisi-sisi lain yang menguasai orang tersebut, contohnya aturan" (Leo Tolstoy, 1983) dalam kalimat ini membuktikan adanya sebagian orang yang membungkam kejujuran untuk kepentingan pribadi, tidak halnya dengan para pelaku seni mural, mereka berusaha untuk berlaku jujur atas keadaan yang memang nyatanya sedang terjadi, mereka berani mengedepankan kepentingan orang banyak daripada dirinya dengan mengkritik di publik melalui karyanya. Maka dari itu, seharusnya peristiwa penghapusan mural pada bulan Agustus 2021 itu tidak dilakukan karena sama dengan membungkam kebenaran dan bertolak belakang dengan sistem pemerintahan di Indonesua yang menganut sistem demokrasi dan merenggut hak kebebasan berekspresi manusia apalagi yang bertujuan baik.

Eksistensi dan prinsip para pelaku seni mural di Kecamatan Majalaya juga relevan dengan pemikiran filosofis Leo Tolstoy. Tolstoy mengedepankan suatu nilai ekpsresi dalam seni dan menolak hanya melihat sisi estetika saja, jauh dari itu Tolstoy menaruh harapan besar bahwa melalui seni mampu membawa manusia ke arah yang lebih baik dalam kehidupannya melalui karya-karya yang dipersembahkan pada publik, tentu para pelaku seni mural di Kecamatan Majalaya pun mengedepankan prinsip nilai-nilai moral sejalan dengan argumenargumen Leo Tolstoy dalam berbagai buku dan tersirat dalam novel-novel karyanya, dengan begitu, eksistensi seni mural di Kecamatan Majalaya memiliki nilai filosofis yang berlandaskan pada tokoh filsuf seni Leo Tolstoy.

\section{Kesimpulan}

Sebagai manusia yang terbentuk dari jasmani dan rohani, tentu kebutuhan dalam hidupnya bukan sekedar makan dan minum, namun ada kebutuhan rohani yang harus dipenuhi, contohnya berkesenian. Seperti yang peneliti lakukan dengan meneliti seni mural yang bereksistensi di tempat tinggal sendiri yaitu di Kecamatan Majalaya dengan tujuan menelisik makna filosofis yang terkandung dalam seni mural dengan tinjauan filsafat seni Leo Tolstoy. Terdapat beberapa hal yang peneliti temukan dan simpulkan dalam penelitian ini. Pertama, prinsip-prinsip dalam bermural yang dilakukan para pelaku seni di Kecamatan Majalaya, disimpulkan relevan dengan prinsip-prinsip filosofis Leo Tolstoy, kedua, 
Jurnal Riset Agama, Volume 1, Nomor 3 (Desember 2021): 292-306

Tiara Rahma Kurnia/Seni Mural Di Kecamatan Majalaya: Tinjauan Filsafat Seni Leo Tolstoy

tindakan penghapusan mural berbentuk kritik di sejumlah kota di Indonesia pada bulan Agustus 2021 lalu seharusnya tidak terjadi karena dari zaman dulu keberadaan seni mural tidak terlepas dari bentuk penyampaian kritik dan dari dulu seni mural sudah diakui keberadaannya di Indonesia sebagai negara demokrasi karena dari mural diajarkan mengkritik dengan tidak melakukan tindakan-tindakan kriminal, bahkan mural membantu perekenomian para pelaku mural, khususnya pelaku mural Kecamatan Majalaya. Peneliti menyadari masih kurang komprehensif dalam segi pengambilan data dan selain itu juga banyak kesenian yang dapat diteliti selain seni mural. Peneliti berharap penelitian ini dapat bermanfaat dan menambah wawasan bagi pembacanya dalam lingkup akademisi maupun non akademisi agar sebagai kajian bersama terkhusus dalam bidang filsafat seni Leo Tolstoy. Peneliti merekomendasi agar ada penelitian lebih detail atas seni mural di Kecamatan Majalaya untuk terus mendorong eksistensinya.

\section{Daftar Pustaka}

Candra, C. O. (2013). Pesan Visual Mural Kota Karya Jogja Mural ForumYogyakarta. Universitas Negeri Yogyakarta.

Chesterton, G. K. (1994). Leo Tolstoy. In The Chesterton Review (Vol. 20, Issue 1). https:// doi.org/10.5840/chesterton19942012

Ikilhojatim.com. (2020). Kritik Pemerintah, Seniman Kirim Pesan Lewat Gambar Mural. Ikilhojatim.com. https://ikilhojatim.com/kritik-pemerintahseniman-kirim-pesan-lewat-gambar-mural/

IMURAL. (2021). Pengertian Mural, Sejarah, Perkembangan Dan Perbedaan Mural Dengan Seni Lukis Lainnya. Imural.

https://www.imural.id/blog/pengertian-mural/

Islam, M. R., \& Ukir, D. S. (n.d.). Makna Religius Islam Dalam Seni Ukir Macan Kurung. 255-269.

Iswandi, H. (2016). Seni mural sebagai unsur politik dalam kehidupan sosial. Besaung: Jurnal Seni Desain Dan Budaya, 1(1), 9-14. http://ejournal.uigm.ac.id/index.php/Besaung/article/view/118

Leo Tolstoy. (1983). Tuan dan Hamba (1st ed.). PT. BPK Gunung Mulia.

Leo Tolstoy. (2003). Kalender Kearifan (Ribut Wahyudi (ed.); 1st ed.). Bentang Budaya.

Leo Tolstoy. (2007). Anna Karentina (Candra Gautama (ed.); 1st ed.). KPG (Kepustakaan Populer Gramedia).

Leo Tolstoy. (2009). The Kreutzer Sonata (Anwar Kholid (ed.); 1st ed.). Jalasutra.

Mawardi, K. (1970). Seni Sebagai Ekspresi Profetik. Ibda` : Jurnal Kajian Islam Dan Budaya, 11(2), 131-147. https://doi.org/10.24090/ibda.v11i2.74

Muhammad, A. A. (2003). Bayang Baur Sejarah (A. D. Sukini (ed.); 1st ed.). 
Jurnal Riset Agama, Volume 1, Nomor 3 (Desember 2021): 292-306

Tiara Rahma Kurnia/Seni Mural Di Kecamatan Majalaya: Tinjauan Filsafat Seni Leo Tolstoy

Tiga Serangkai.

Nababan, R. S. (2019). Karya Mural Sebagai Medium Mengkritisi Perkembangan Jaman (Studi Kasus Seni Mural Karya Young Surakarta). International Conference on Art, Design, Eduvation, and Cultural Studies (ICADECS), 2019.

Narasi. (2021). Pembuat Mural "Tuhan, Aku Lapar!!": "Kami Disuruh Minta Maaf" | Namanya Juga Lyfe.

https://www.youtube.com/watch?v=KR8Yx8tQ3lo

Obed Bima Wicandra. (2005). Berkomunikasi Secara Visual Melalui Mural Di Jogjakarta. Nirmana, 7(2), 126-133.

http://puslit2.petra.ac.id/ejournal/index.php/dkv/article/view/16 518

Pandanwangi, A., Ida, I., Ratnadewi, R., Manurung, R. T., Budiman, I., \& Vincent, V. (2021). Tingkat Kebahagiaan Masyarakat setelah Adanya Mural di Kelurahan Sukawarna Kecamatan Sukajadi Bandung. Ideas: Jurnal Pendidikan, Sosial, Dan Budaya, 7(2), 137. https://doi.org/10.32884/ideas.v7i2.365

Penelitian, J., \& Ushuluddin, I. (2021). Bencana Kemanusiaan dalam Tinjauan Filsafat Perenial Abdillah. 1(2), 74-81. https://doi.org/10.15575/jpiu.12199

Ratu, L. (2016). Seni Sebagai Ekspresi.

http://ratularasblogadress.blogspot.com/2016/12/seni-sebagaiekspresi.html

Sobur, A. (2007). Karya Seni sebagai Media. Mediator: Jurnal Komunikasi, 8(2), 211-220. https:// doi.org/10.29313/mediator.v8i2.1245

Sumardjo, J. (2000). Filsafat Seni (1st ed.). penerbit ITB Bandung.

Tolstoy, L. (n.d.). what is art. 148, 148-162.

TvOneNews. (2021). Mural Berbalut Kritik Dibongkar, Sujiwo Tejo: Malah Nempel Dikenangan | Kabar Petang Pilihan to One. https:/ / www.youtube.com/watch?v=CHGkZ7Nq2IY

Wikipedia. (2021). Majalaya, Bandung. Wikipedia. https://id.wikipedia.org/wiki/Majalaya,_Bandung 